\title{
YESUS SEBAGAI GURU \\ DITINJAU DARI PENDEKATAN MENGAJAR DAN RELEVANSINYA BAGI GURU AGAMA KATOLIK
}

\author{
Natalis Sukma Permana \\ natalissukmapermana@yahoo.com \\ STKIP Widya Yuwana
}

\begin{abstract}
The figure of Jesus as a teacher is clearly different from the average teacher. Jesus was recognized as a teacher not only by His disciples, but by many who heard His teachings. Jesus is called the Teacher because Jesus' teacher training is based on "teaching" activities. The uniqueness of his teaching was different from that of the Rabbis of his day. Jesus is truly a teacher who has the competence to teach from the side of His personality. In His teaching Jesus had clear goals and directions, to achieve His learning goals Jesus used strategies such as learning and was supported by the use of approaches that were easy for his students to understand. This paper aims to (1) show Jesus as a teacher, (2) the uniqueness of Jesus' teaching (3) the teaching techniques practiced by Jesus (4) and its relevance for Catholic religious teachers. The important point of the results of this study is that Catholic religion teachers must have Jesus-like character and skills to teach well according to Jesus' example. These teaching skills have a big influence on students' attention to learning. This research will use descriptive quantitative and qualitative approaches.
\end{abstract}

Keywords: Jesus, Teaching Approach, Catholic Religion Teacher

\section{PENDAHULUAN}

Menjadi seorang guru memiliki tanggung jawab yang sangat besar, di mana guru merupakan profesi yang sangat mulia dan merupakan suatu kepercayaan yang diberikan Tuhan bagi setiap orang. Guru merupakan faktor penting dalam menyukseskan kegiatan belajar. Dimanapun kegiatan belajarmengajar memerlukan guru yang berkualitas. Guru pula yang memberi dorongan agar peserta didik berani berbuat benar dan berani bertanggung jawab atas setiap perbuatannya. Dalam hal ini guru memberikan keteladanan, 
memberikan contoh yang baik kepada peserta didiknya supaya dapat menirunya.

Sebagai seorang Guru, Yesus sempurna dari segi Ilahi maupun insani. Ia “datang sebagai guru yang diutus Allah” (Yoh 3:2). Yesus adalah Guru yang memiliki kepribadian dengan selalu memberi teladan tidak hanya dengan kata-kata karena perbuatan seseorang lebih berpengaruh dari pada perkataannya. Ia selalu memperhatikan keperluan orang lain dan hasrat untuk menolong orang lain. Yesus selalu melihat bahwa relasiNya dengan para murid menjadi sarana untuk membina cita-cita, pandangan dan perubahan hidup murid-muridNya.

Yesus sebagai Guru berdasarkan kata didaskalos untuk pengajar (teacher). Yesus disebut sebagai Guru, karena keguruan Yesus didasarkan pada aktivitas "mengajar" (to teach). Dalam tulisan ini akan mencoba melihat sisi keguruan Yesus, keunikan Yesus sebagai guru, dan metode mengajar. Selain itu perlu dipahami bahwa murid-murid tidak terbatas pada kedua belas murid tetapi kita, manusia yang percaya dan terus belajar dari-Nya untuk mendapat keselamatan dan bersatu dengan Allah. Oleh karena itu kita harus terus mencari Guru Sejati dan "berguru” kepada-Nya.

\section{PEMBAHASAN}

\subsection{Yesus Sebagai Guru}

Dalam Alkitab, selain Yesus diberi gelar Mesias, Tuhan, Anak Allah, Anak Manusia, Hamba, juga Yesus disapa sebagai Rabi oleh para pengikutnya dan bahkan oleh penentangnya, termasuk orang-orang Farisi. Kata rabi berasal dari bahasa Ibrani rabi yang berarti besar dipakai sebagai kehormatan. Pada akhir abad ke-2 sebelum Masehi rabi dipakai untuk menyebut Guru, dan kata rabi, yang artinya Guru saya. Selanjutnya kata rabi menjadi gelar resmi untuk Guru Torah Yahudi.

Dalam Perjanjian Baru muncul dua belas kali untuk dikenakan pada Diri Tuhan Yesus, empat kali muncul dalam Injil Sinoptik dan delapan kali muncul dalam Injil Yohanes. Ajaran Yesus bukan kutipan, atau dukungan guru-guru lain. Yesus tidak pernah mengutip ucapan-ucapan para ahli, atau guru besar lainnya untuk menguatkan ajaran-Nya kecuali perkataan Allah yang disampaikan melalui nabi-nabi Perjanjian Lama. Perkataan Yesus sendiri dianggap-Nya telah cukup, karena pengajaran-Nya jelas, meyakinkan, dan penuh kuasa, wibawa (Mrk. 1 : 22).

Kunci utama keberhasilan ajaran Yesus ialah "teladan” dan kehidupan

yang dipraktekkan-Nya sendiri. Setiap ajaran Yesus selalu Nampak dalam kehidupan-Nya, seperti kesengsaraan, penderitaan, kecaman, penganiayaan, dan sebaliknya terhadap kehidupan yang demikian Yesus tidak melakukan tindakan 
pembalasan. Sehingga tekanan ajaran Yesus bukan dalam doktrin-doktrin agama, tetapi “teladan", yang dapat dituruti setiap murid-Nya. Dalam melakukan pengajarannya Yesus memiliki aspek-aspek yang patut untuk diteladani bagi model pendidikan saat ini juga teladan bagi para pendidik, terutama pendidik iman.

\subsection{Keunikan Pengajaran Yesus}

Yesus sebagai Seorang Guru memiliki berbagai gaya keunikan mengajar yang berbeda dengan para rabi lainnya, sehingga pengajaran Yesus mampu menarik perhatian khalayak ramai dan bahkan dapat dijadikan model teladan bagi para pendidik. Dalam tulisan ini penulis mencoba menguraikan dua hal keunikan pengajaran Yesus.

\subsubsection{Guru yang Mencari Murid}

Salah satu keunikan Yesus dalam mengajar adalah Guru yang mencari murid dan bukan murid yang mencari Guru, seperti yang terjadi saat ini. Dalam Injil Matius mencatat tentang Yesus sedang mencari murid-murid-Nya:

"Dan ketika Yesus sedang berjalan menyusur danau Galilea, Ia melihat dua orang bersaudara, yaitu Simon yang disebut Petrus, dan Andreas, saudaranya. Mereka sedang menebarkan jala di danau, sebab mereka penjala ikan. Yesus berkata kepada mereka: "Mari, ikutlah Aku, dan kamu akan Kujadikan penjala manusia. Lalu merekapun segera meninggalkan jalanya dan mengikuti Dia. Dan setelah Yesus pergi dari sana, dilihat- Nya pula dua orang bersaudara, yaitu Yakobus anak Zebedeus dan Yohanes saudaranya, bersama ayah mereka, Zebedeus, sedang membereskan jala di dalam perahu. Yesus memanggil mereka dan mereka segera meninggalkan perahu serta ayahnya, lalu mengikuti Dia” (Mat 4:18-22)

Pembelajaran model Guru mencari murid merupakan keunikan model pembelajaran Yesus yang berbeda dengan para rabi di kalangan Yahudi pada waktu itu. Yesus selalu mencari murid-murid untuk dijadikan sebagai pengikutnya untuk diajar supaya mereka dapat meneruskan ajaran-Nya. Tetapi bagi tradisi Yahudi murid-murid selalu mencari para rabi. Hal yang lebih menarik pada Matius 4:18-22 adalah Yesus mencari murid dengan cara berjalan menyusur danau Galilea, model ini asing bagi para guru di zaman itu. Keunikan pengajaran Yesus di sini yang berbeda dengan para rabi pada saat itu adalah murid-muridNya langsung meninggalkan pekerjaan dan mengikut Yesus.

Yesus mendapatkan murid- murid dalam satu cara yang sangat berbeda dengan para rabi Yahudi. Pada umumnya murid-murid Yahudi mencari guru-guru mereka, tetapi murid-murid Yesus bukan mencari Dia, melainkan Ia yang mencari 
dan memanggil mereka di tengah-tengah aktivitas-aktivitas mereka setiap hari (Yoh 1:35-51). Selain itu, murid- murid Yesus juga harus meninggalkan segala profesi dan masa lalu mereka yang berdosa (Luk 5:27-32) untuk secara total, penuh kesetiaan, dan seumur hidup mengikuti Yesus sebagai murid-murid-Nya.

Dalam Injil Matius dituliskan bahwa Yesus seorang Guru yang mencari murid dengan tujuan yang jelas, sebab dengan tujuan yang jelaslah maka akan mempengaruhi seluruh proses pembelajaran. Guru yang mengajar dengan sasaran yang jelas, murid yang mengikuti proses pembelajaran pun jelas arahnya. Tujuan pembelajaran dalam Matius adalah murid-murid mampu menjadi penjala manusia.

\subsubsection{Memenuhi Kebutuhan Pengikutnya}

Yesus mengajar sebagai Guru dengan mendekati para pendengar yang berbeda-beda, Ia peduli dengan kebutuhan orang-orang diajar-Nya, Ia mengajar dengan penuh kasih dan kemurahan-Nya sebagaimana terlihat ketika Ia menolong setiap orang yang mengalami kesulitan. Yesus mengajar dengan kuasa, sehingga orang menderita sakit disembuhkan seperti, menyembuhkan mertua Petrus menyembuhkan orang menderita kusta menyembuhkan orang lumpuh, menyembuhkan orang yang mati sebelah tangan, menyembuhkan hamba perwira yang sakit lumpuh menyembuhkan seorang wanita sakit menyembuhkan orang tuli dan gagap, menyembuhkan orang buta di Betsaida, menyembuhkan dua orang buta, menyembuhkan Bartimeus yang buta, menyembuhkan wanita bungkuk yang 18 tahun dirasuk roh jahat, menyembuhkan anak yang sakit ayan, Yesus menyembuhkan 10 orang sakit kusta, menyembuhkan telinga Malkus yang dipenggal Petrus.

Demikian juga Yesus mengajar dengan kuasa sangat nyata di dalam pelayanan pengusiran setan seperti, Yesus mengusir roh jahat di sinagoge, roh Legion di Gerasa, mengusir roh jahat dari orang Siro-Fenisi di Tirus, mengusir roh yang membuat seorang anak bisu, mengusir setan yang menyebabkan bisu, mengusir setan yang menyebabkan bisu dan buta. Bahkan pengajaran Yesus disertai dengan membangkitkan orang mati, yaitu membangkitkan anak Yairus, seorang kepala rumah ibadah dan membangkitkan Lazarus (Yoh 11:1-44).

\subsection{Kompetensi Mengajar}

\subsubsection{Kecakapan Mengajar}

Menurut Valeria A. Wilson (1981) kecakapan Yesus dalam mengajar dapat dilihat dari lima kompetensi. Pertama, Yesus adalah Guru yang memiliki kecapakan membaca yang unggul (art of reading). Dari Injil Lukas dapat ditemukan bahwa Yesus dapat membaca Kitab Suci dengan sangat baik, tepatnya pada saat Yesus membacakan Kitab Yesaya, ia menemukan sebuah nas yang isinya meneguhkan keberadaan Tuhan (Luk. 4:16-20). Kedua, Yesus adalah Guru 
yang memiliki kemampuan menulis yang unggul (art of writing). Ketiga, sebagai seorang Guru Yesus memiliki penguasaan bahasa dengan baik, salah satunya bahasa Ibrani. Dalam keadaan yang sangat berat, Yesus dapat berbahasa dengan baik. Dari Injil Matius dapat ditemukan saat Yesus dicobai lalu Yesus menulis ditanah (Mat.27:46). Keempat, dalam pengajarannya selalu bersumber dari Allah Bapa. Yesus selalu mengutip ayat-ayat Kitab suci, dalam pengajaran dan khotbahnya selalu berbasis Kitab Suci.

\subsubsection{Memiliki Kecerdasan Emosional dan Kecerdasan Sosial Guru}

Yesus adalah Guru yang unggul dalam hal sikap (attitude), karakter dan kepribadian. Yesus memiliki emosi atau perasaan, tetapi Yesus memiliki kekuatan penuh untuk mengendalikan emosi atau perasaannya. Yesus bukanlah tipe Guru yang mudah terombang-ambing perasaannya, atau Guru yang tidak bisa mengontrol emosi, dalam istilah pembelajaran Yesus memiliki kecerdasan emosional (emotional intelligence).

Sikap Yesus di Bait Allah dan mengusir semua orang yang melakukan jual beli di bait Allah sampai membalikkan meja-meja penukar uang dan bangku penjual merpati (Mat.21:12) bukankan itu tindakan kekerasan? Bukankan itu tindakan emosional? Dari sisi ke Allahan Yesus, sikap Yesus merupakan keprihatinan terhadap dosa manusia, sedangkan dari sisi pembelajaran sikap itu merupakan sentuhan simbolik dalam proses mengajar. Tindakan itu mengajarkan bahwa sebagai seorang pengajar harus memiliki prinsip penting "Ada tertulis: Rumah-Ku akan disebut rumah doa. Tetapi kamu menjadikannya sarang penyamun” (Mat. 21:13). Sikap itu tidak menunjukkan karakter kekerasan dalam diri Yesus, Yesus bisa marah, namun tidak dikuasai oleh amarah.

Sebagai seorang Guru, Yesus juga memiliki kecerdasan sosial yang baik, yaitu kecerdasan sosial untuk berelasi, berkomitmen, dan bekerjasama dengan orang lain. Yesus mampu bergaul baik dengan para murid dalam persekutuan dan persahabatan. Yesus hidup bersama para murid, makan bersama, tidur bersama, dan melayani. Para murid tidak sungkan-sungkan untuk berbicara dan bertanya kepada Yesus (Mat. 13:36;14:28;19:27; Luk 9:33;17:5). Pergaulan Yesus sangat luas, Yesus bisa duduk dengan orang dari berbagai kalangan. Bahkan Yesus mau berinteraksi dengan pemungut cukai dan dengan mereka yang mendapat cap sebagai sampah masyarakat. Kecerdasan sosial yang ada dalam diri Yesus memungkinkan Yesus dapat bekerjasama dengan bermacam-macam orang.

\subsubsection{Agen Perubahan Masyarakat}

Dalam hidup bermasyarakat, Yesus adalah warga yang baik. Soal membayar pajak misalnya, Yesus mengajarkan prinsip membayar pajak, seperti kata-Nya "Berikanlah kepada Kaisar apa yang wajib kamu berikan kepada Kaisar 
dan kepada Allah apa yang wajib kamu berikan kepada Allah!” (Mrk. 12:17). Yesus adalah guru yang aktif memberikan kontribusi bagi pembangunan masyarakat. Yesus memberikan pelayanan kepada kaum miskin dan papa, orangorang sakit, orang-orang yang terpinggirkan. Ketika lima ribu orang mengikuti Dia, Yesus tidak membiarkan mereka kelaparan. Yesus mengajari kepada para murid untuk memberi mereka makan, tindakan ini jelas menunjukkan bahwa Yesus memiliki kepedulian sosial terhadap masyarakat.

Sebagai Guru dan agen pembaharu masyarakat, Yesus tidak segan memberikan kritik-kritik sosial. Yesus mengecam keras tindakan para ahli taurat dan para imam dalam hal penyalahgunaan kekuasaan mereka (Mat.23:1 -12). Sebagai contoh tindakan, Yesus mengecam praktik perdagangan di Bait Allah dan mengusir semua pedagang yang berjualan di sana (Yoh. 2:1-15). Ketokohan Yesus di masyarakat secara psikologis menumbuhkan rasa bangga, yakin dan rasa hormat dari para murid terhadap pribadi Yesus.

\subsubsection{Guru yang Mencerdaskan}

Yesus adalah sosok Guru yang memicu jiwa kritis para murid-Nya. Yesus selalu membuka pertanyaan, diskusi, dan bahkan membantah-Nya. Yesus bukanlah sosok Guru yang mendikte murid dengan ajaran-ajaran. Setelah mengajar dengan perumpamaan, tidak jarang Yesus menerima interupsi dan pertanyaan dari para murid. Misalnya, setelah mengajar dengan perumpamaan, Yesus menerima interupsi dari pada murid "Mengapa Engkau berkata-kata kepada mereka dalam perumpamaan?" (Mat. 10.13). Lalu Yesus memberi jawaban kepada mereka (Mat. 13:11-23) dan justru memberi banyak perumpamaan lagi (Mat. 13:24-33). Lalu para murid tetap meminta penjelasan lebih detail lagi kata mereka "Jelaskanlah kepada kami perumpamaan tentang lalang di ladang itu." (Mat. 13:36). Setelah memberi tambahan perumpamaan dan penjelasan, Yesus mengevaluasi, katanya “mengertikah kamu semuanya itu?” (Mat. 13:51a). Mereka pun menjawab "Ya kami mengerti” (Mat. 13:51b).

Sebagai seorang Guru, Yesus tidak pernah menolak kaum yang mengkritisi ajarannya, bahkan pertanyaan-pertanyaan yang sengaja dilontarkan untuk menjebak-Nya. Misalnya saat kaum Farisi bertanya "Katakanlah kepada kami pendapat-Mu: Apakah diperbolehkan membayar pajak kepada Kaisar atau tidak?” (Mat.22:17). Meskipun Yesus mengetahui pertanyaan itu untuk menjebaknya, Yesus justru menjawab dengan cerdas menggunakan pertanyaan sehingga mereka heran dan tidak bertanya lagi (Mat. 22:18-22).

Kekhasan Yesus dalam memberikan jawaban atas pertanyaan para murid dapat secara positif dilihat: (1) Yesus tidak pernah menertawakan orang yang bertanya, (2) Yesus tidak pernah membatasi pertanyaan-pertanyaan, (3) Yesus tidak pernah menjawab “Aku tidak tahu” dan Yesus lebih mengarahkan proses 
belajar daripada memuaskan rasa penasaran, (4) jawaban-Nya mengandung perumpamaan. Semua itu menunjukkan bahwa Yesus mengajar dengan sikap kritis yang cerdas (Baskoro, 2018:21)

Terhadap para murid yang kritis secara logika, Yesus memberikan jawaban yang positif dan memberikan evaluasi untuk pembenahan. Sikap Yesus terhadap Thomas yang mengkritisi dan meragukan kebangkitannya, Yesus memiliki teknik khusus dengan menunjukkan bekas-bekas luka penyaliban pada tubuh-Nya. Setelah itu Yesus menegur Thomas untuk lebih beriman (Yoh. 20:29). Hal ini menunjukkan bahwa Yesus tidak mau para murid menerima kebenaran tanpa mengkritisinya. Sebagai seorang Guru, Yesus juga mengapresiasi kecerdasan Nikodemus. Dalam diskusinya sangat terlihat ketajaman berpikir Nikodemus (Yoh 3:1-21).

Dari beberapa fakta di atas, Yesus benar-benar Guru yang mencerdaskan murid-Nya. Murid yang belum paham diberi-Nya kesempatan bertanya, bahkan yang mau protes diberikannya kesempatan bicara. Sedangkan murid yang sudah cerdas diajaknya berdiskusi pada level intelektualitas yang lebih tinggi. Dengan demikian dapat disimpulkan bahwa pembelajaran Yesus merupakan pembelajaran yang mencerdaskan.

\subsection{Tujuan Pembelajaran}

Yesus adalah Guru yang memiliki tujuan pembelajaran yang jelas. Secara umum tujuan dari pengajaran dan pembelajaran-Nya adalah membawa orang pada keselamatan. Hal itu dikatakan secara jelas “Aku datang, supaya mereka mempunyai hidup, dan mempunyainya dalam segala kelimpahan (Yoh. 10:10). Dari sisi Allah (sola gratia), keselamatan adalah anugerah, sedangkan dari sisi manusia keselamatan membutuhkan tindakan manusia berupa iman (sola fide). Tujuan pembelajaran Yesus adalah menumbuhkan iman dalam diri manusia sehingga mereka beroleh keselamatan.

Selain itu, Yesus juga memiliki tujuan instruksional yang jelas untuk mempertobatkan manusia "Tidak! kata-Ku kepadamu. Tetapi jikalau kamu tidak bertobat, kamu semua akan binasa atas cara demikian” (Luk. 13:3). Kata-kata Yesus ini jelas bahwa pertobatan merupakan tujuan dari pengajaran. Pertobatan itu diharapkan membawa perubahan cara hidup, bukan seperti orang yang berubah karena takut akan hukuman, tetapi tidak sungguh-sungguh menyesali diri (Mat. 24:7).

Pembelajaran Yesus sangat efektif merubah cara hidup manusia. Yesus mengajarkan prinsip kasih secara vertikal dan horizontal. Pada Injil Markus 12:30 jelas dikatakan bahwa mengasihi Allah berarti memastikan Allah adalah yang terpenting, menghormati Allah, melakukan kehendak Allah sebagaimana mencintai seorang sahabat. Sedangkan ajaran kasih secara horizontal pada Markus 
12:31 "Dan hukum yang kedua ialah: Kasihilah sesamamu manusia seperti dirimu sendiri. Tidak ada hukum lain yang lebih utama dari pada kedua hukum ini."

Dari percakapan dan sikap Yesus kepada Petrus yang menyangkalnya, Yesus mengajarkan kasih "agape" kasih ilahi yang tanpa pamrih. Injil Yohanes 21:15-17 mencatat percakapan Yesus dengan Petrus pasca kebangkitan. Dalam percakapannya, Yesus bertanya kepada Petrus apakah Petrus mengasihi-Nya dengan kasih yang “agape” namun Petrus hanya mampu mengasihi Yesus dengan kasih "philia", yaitu kasih persahabatan.

Yesus juga mengajarkan kasih yang sungguh radikal dan sikap rela berkorban. Kasih yang radikal dimaksudkan agar orang memiliki nilai kasih di atas rata-rata yakni mampu mengampuni dan membalas kejahatan dengan kebaikan. Tindakan Yesus sungguh mencerminkan bahwa kehadirannya untuk melayani bukan untuk dilayani.

Selain hal di atas, sebagai seorang Guru, Yesus tidak lupa mengajarkan pentingnya memiliki kualitas hidup rohani yang baik. Dalam hal berdoa, Yesus mengajarkan agar murid-Nya tidak memiliki kesombongan rohani, “dan apabila kamu berdoa, janganlah berdoa seperti orang munafik. Mereka suka mengucapkan doanya dengan berdiri dalam rumah-rumah ibadat dan pada tikungan-tikungan jalan raya, supaya mereka dilihat orang. Aku berkata kepadamu: Sesungguhnya mereka sudah mendapat upahnya” (Mat. 6:5).

\subsection{Strategi Pembelajaran}

\subsubsection{Pembelajaran Ekspositori}

Dalam mengajar, Yesus menggunakan metode ekspositori yaitu dengan bertutur-kata untuk menjelaskan materi pelajarannya. Injil banyak mencatat tentang bagaimana Yesus mengajar dengan cara memberi ceramah dan dengan menggunakan teks Kitab Suci untuk ceramah.

Khotbah di bukit menunjukkan bagaimana Yesus menjelaskan prinsipprinsip yang ada di dalam perjanjian lama. Yesus menjelaskan soal orang yang berdukacita, seperti dalam Injil Matius 5:4 "Berbahagialah orang yang berdukacita, karena mereka akan dihibur”. Di sini Yesus juga mengacu pada nubuat Yesaya tentang tahun rahmat Tuhan dan hari pembalasan Allah (Yes. 6:2). Pada waktu Yesus menjelaskan kebahagiaan orang yang lemah lembut (Mat. 5:5), Yesus mengacu pada Mazmur 37:11 "Tetapi orang-orang yang rendah hati akan mewarisi negeri dan bergembira karena kesejahteraan yang berlimpah-limpah”. Dari kedua fakta tersebut menunjukkan bahwa Yesus dapat menjelaskan teks Kitab Suci secara akurat.

Strategi pembelajaran ekspositori merupakan strategi pembelajaran aktif dengan memadukan metode ceramah. Yesus sangat memiliki keahlian komunikasi verbal serta memiliki kreativitas yang cukup tinggi. Tujuan dari strategi 
pembelajaran ini adalah membuat para murid mengerti dan memahami materi yang disampaikan oleh Guru.

\subsubsection{Pembelajaran Inkuiri}

Dalam pengajarannya Yesus memotivasi para murid untuk mencari dan menemukan sendiri akan kebenaran-kebenarannya. Strategi pembelajaran ini disebut dengan strategi pembelajaran inkuiri. Strategi ini tampak saat Yesus mengutuk pohon ara (Mrk. 11:12-14), dari tindakannya ini Yesus hendak mengajarkan soal iman.

Dalam perikop Injil Markus 11:12-14, di ayat 12 sampai 14 Yesus mengutuk pohon ara seolah-olah sebagai bentuk ekspresi spontan. Yesus mengutuk pohon ara supaya pohon itu mati. Para murid dapat menafsirkan bahwa ekspresi Yesus tersebut sebagai bentuk ekspresi emosional. Namun, jika dicermati sampai ayat ke 24, tindakan Yesus dapat dilihat sebagai sebuah proses mengajar.

Yesus berusaha menciptakan suasana belajar agar para murid aktif belajar. Proses inkuiri terjadi dalam diri Petrus. Keesokan harinya Yesus membawa para murid melewati pohon ara itu, para murid "melihat" pohon yang sudah kering karena dikutuk Yesus (Mrk 11:20). Proses inkuiri selanjutnya adalah "teringat” (Mrk. 11:21), yang berarti mengingat dan memikirkannya. Hal ini jelas merupakan proses belajar.

Dari proses melihat dan mengingat itu mendorong Petrus untuk berkomunikasi dengan Yesus. Sampai pada tahap ini Yesus melihat bahwa Petrus telah belajar sesuatu dan berarti siap untuk menerima ajaran baru, Yesus langsung memberi pelajaran tentang prinsip iman dan doa (Mrk. 22-24).

Proses pembelajaran inkuiri yang lain dapat terlihat pada saat Yesus menunjukkan kuasa-Nya, yaitu saat Yesus berjalan di atas air (Mat. 14:22-33). Dari awal Yesus berusaha mengkondisikan agar para murid belajar mandiri. Yesus memerintahkan para murid untuk berlayar tanpa diri-Nya, hal ini dapat dilihat sebagai pemberian tugas lapangan tanpa dibimbing langsung oleh Guru. Dalam peristiwa itu terjadi badai, dan Yesus menghampiri para murid dengan berjalan di atas air. Para murid pada mulanya salah mengidentifikasi, mereka menganggap bahwa Yesus hantu. Dalam hal ini, sosok keguruan Yesus sangat terlihat, Yesus langsung meluruskan jawaban para murid dan mengatakan bawa yang mereka lihat adalah Yesus.

Keberhasilan proses belajar dapat dilihat saat para murid mampu mengidentifikasi fakta tentang pribadi Yesus "dan orang-orang yang ada di perahu menyembah Dia, katanya: "Sesungguhnya Engkau Anak Allah." (Mat. 14:33). Selain itu, pembelajaran inkuiri yang dilakukan oleh Yesus juga mendorong para murid untuk melakukan riset induktif dan menarik kesimpulan. Proses 
pembelajaran itu dapat terlihat saat Yesus bertanya kepada para murid tentang siapa Diri-Nya dan menurut para murid itu sendiri.

\subsection{Metode Mengajar}

Jika dicermati sepintas, pengajaran Yesus seperti tidak terencana dengan baik. Namun anggapan itu tidaklah tepat. Sebagaimana seorang pelukis melihat gambar yang akan dilukis-Nya di atas kain kanvas dan seperti seorang pemahat membayangkan bentuk yang akan dipatahkan pada batu, demikian pula Tuhan Yesus melihat dalam diri setiap murid-Nya pribadi yang akan timbul dan perlu dibina secara optimis dan dengan penuh kesabaran sehingga gambar itu dijadikan-Nya. Namun selalu ada harapan bagi yang paling jahat dan lemah sekalipun (J. M. Price, 1968:52). Untuk mengetahui kebutuhan setiap murid Yesus menggunakan metode bertanya dan konteks sosial budaya. Dengan tujuan contoh-contoh yang diberikan oleh Yesus dekat dengan kehidupan para murid.

Dalam pengajarannya, Yesus juga menggunakan metode konseling baik pribadi maupun berkelompok. Yesus memulai pengajaran-Nya dari pengalaman hidup orang yang mendengar-Nya. Yesus menyampaikan ajaranNya sesuai dengan keadaan orang yang ada dihadapan-Nya. Yesus mengajar orang dari pengalaman hidup orang itu sendiri dan mengantarnya ke tujuan yang dikehendaki-Nya. Sebagai contoh dari Injil Yoh 4:10, terlihat bagaimana Yesus memberi pengajaran kepada wanita tuna susila di tepi sumur Yakub, Yesus memulai dengan "air" hal yang menarik bagi wanita itu kemudian diantar-Nya kepada air hidup. Pengajaran yang sesuai dengan perhatian, keperluan, dan menggunakan bahasa yang dikenal merupakan kebenaran dalam mengajar.

Dalam mengajarkan kebenaran, Yesus juga menggunakan metode demonstrasi yang menarik. Aksi Yesus yang membasuh kaki para murid jelas merupakan metode demonstrasi. Pertama, aksi Yesus berhasil menumbuhkan minat belajar, terlihat ketika Petrus bertanya "Tuhan Engkau hendak membasuh kakiku?”. Kedua, proses pembelajaran menjadi dinamis ketika terjadi dialog antara murid dan Guru. Ketiga, setelah proses dialog Yesus memberikan evaluasi dengan memberi pertanyaan "mengertikah kamu apa yang telah kuperbuat kepadamu?” (Yoh 13:12). Keempat, sebagai penutup kegiatan belajar yang mengandung pesan pembelajaran. Yesus menyampaikan dengan tegas:

"Kamu menyebut Aku Guru dan Tuhan, dan katamu itu tepat, sebab memang Akulah Guru dan Tuhan. Jadi jikalau Aku membasuh kakimu, Aku yang adalah Tuhan dan Gurumu, maka kamu pun wajib saling membasuh kakimu; sebab Aku telah memberikan suatu teladan kepada kamu, supaya kamu juga 
berbuat sama seperti yang telah Kuperbuat kepadamu” (Yoh. 13:13-15).

Dalam menggunakan metode demonstrasi sangat jelas bahwa Yesus melakukan dengan baik dan terstruktur, para murid akan mengingat demonstrasiNya dan menangkap pesan pembelajaran yang disampaikan oleh Yesus.

\subsection{Media Pembelajaran yang Digunakan Yesus}

Sebagai seorang Guru, dalam pengajarannya Yesus menggunakan media yang diciptakan-Nya sendiri. Sebagai contoh, Yesus menggunakan burung di udara, bunga bakung di padang. Jika Yesus menggunakan media alam sejati-Nya Yesus menciptakan sendiri medianya. Hal ini dilihat dari sisi ke Allahan Yesus sebagai pencipta alam semesta.

Selain menggunakan media yang Yesus ciptakan sendiri, Yesus juga menggunakan objek benda mati misalkan uang koin untuk membantu memberikan jawaban soal pajak yang harus diberikan kepada kaisar (Mrk. 12:13-17). Objek benda hidup yang Yesus gunakan adalah manusia. Yesus menggunakan anak kecil untuk menjelaskan tentang kerendahan hati kepada para murid (Mat. 18:1-6).

Yesus juga sosok Guru yang memakai diri-Nya sebagai media atau model pembelajaran. Yesus mengajarkan hal berdoa kepada para murid, Yesus tidak hanya mengajarkan doa itu (mat. 6:5-15; Luk 11:1-13) tetapi Yesus sendiri adalah pribadi pendoa yang berkualitas.

\subsection{Evaluasi Pembelajaran}

\subsubsection{Menilai Secara Objektif}

Selama pelayanannya di dunia sampai setelah naik ke surga, Yesus adalah seorang evaluator. Sebagai contoh saat Yesus menegur para murid "Mengapa kamu takut dan kurang percaya?” (Mat. 8:26), juga di dalam Injil Lukas “Hai kamu orang bodoh, betapa lambannya hatimu, sehingga kamu tidak percaya, segala sesuatu yang dikatakan oleh para nabi” (Luk. 24:25). Dari dua contoh ucapan Yesus tampak bahwa Yesus merupakan sosok yang tegas dalam memberikan evaluasi soal iman.

Sebagai Guru yang adil, Yesus memperlakukan para murid-Nya secara adil dan objektif. Dalam relasi humanistik, antara Guru dan murid seringkali membuat para Guru memperlakukan murid-murid tertentu secara subjektif. Namun tidak demikian dengan Yesus. Injil Yohanes mencatat adanya relasi khusus antara Yesus dengan murid-murid tertentu. Misalnya ada seorang murid yang mendapat sebutan murid yang dikasihi-Nya. Injil Yohanes 13:23 mencatat "Seorang di antara murid Yesus, yaitu murid yang dikasihi-Nya, bersandar dekat kepada-Nya, di sebelah kanan-Nya”. Dalam momen transfigurasi, tidak semua murid memiliki kesempatan untuk menyaksikan, hanya Petrus, Yohanes dan 
Yakobus. Injil Lukas mencatat demikian "Kira-kira delapan hari sesudah segala pengajaran itu, Yesus membawa Petrus, Yohanes dan Yakobus, lalu naik ke atas gunung untuk berdoa. Ketika Yesus sedang berdoa, rupa wajah-Nya berubah dan pakaian-Nya menjadi putih berkilau-kilauan. Dan tampaklah dua orang berbicara dengan Dia, yaitu Musa dan Elia” (Luk. 9:28-30).

Meskipun demikian, perlakuan Yesus kepada Petrus tidak ada relasi istimewa, Petrus juga sering ditegur oleh Yesus. Teguran Yesus kepada Petrus dapat ditemukan dalam Injil Matius "Maka Yesus berpaling dan berkata kepada Petrus: "Enyahlah Iblis. Engkau suatu batu sandungan bagi-Ku, sebab engkau bukan memikirkan apa yang dipikirkan Allah, melainkan apa yang dipikirkan manusia” (Mat. 16-23).

\subsubsection{Menilai dan Memberi Apresiasi}

Sosok Yesus sebagai seorang Guru tidak hanya memberikan evaluasi kepada para murid-Nya, namun Yesus juga memberi apresiasi ketika murid sungguh-sungguh mau belajar dan meraih prestasi belajar yang baik. Yesus tidak segan-segan memberikan pujian. Sebagai contoh peristiwa seorang perwira yang memintakan kesembuhan bagi hamba-Nya yang lumpuh dan menderita, mengingatkan bahwa Yesus sungguh memberikan apresiasi karena seorang perwira mampu melakukan analisa analogis sehingga dapat merumuskan imannya dengan baik. Ketika Yesus bersedia mengunjungi hamba perwira itu untuk menyembuhkannya, sang perwira justru berkata "Tuan, aku tidak layak menerima Tuan di dalam rumahku, katakan saja sepatah kata, maka hambaku itu akan sembuh. Sebab aku sendiri seorang bawahan, dan di bawahku ada pula prajurit. Jika aku berkata kepada salah seorang prajurit itu: Pergi!, maka ia pergi, dan kepada seorang lagi: Datang!, maka ia datang, ataupun kepada hambaku: Kerjakanlah ini!, maka ia mengerjakannya” ( Mat. 8:8-9).

Di mata Yesus seorang perwira ini telah berhasil dalam mempelajari prinsip iman. Prestasi belajar itu sungguh membuat Yesus terheran sehingga Ia berkata "Aku berkata kepadamu, sesungguhnya iman sebesar ini tidak pernah Aku jumpai pada seorang pun di antara orang Israel” (Mat. 8:10). Sebagai seorang Guru Yesus sangat jujur terhadap rasa kagum-Nya dan memberi apresiasi.

\subsection{Identitas Guru Agama Katolik}

Menurut Undang-Undang No. 14 Tahun 2005 tentang Guru dan Dosen, guru adalah pendidik profesional dengan tugas utama mendidik, mengajar, membimbing, mengarahkan, melatih, menilai, dan mengevaluasi peserta didik pada pendidikan anak usia dini jalur pendidikan formal, pendidikan dasar, dan pendidikan menengah. Peranan guru sangat penting dalam dunia pendidikan karena selain berperan mentransfer ilmu pengetahuan ke peserta didik, guru juga 
dituntut memberikan pendidikan karakter dan menjadi contoh karakter yang baik bagi anak didiknya.

Dari penjelasan tersebut diatas dapatlah dipahami bahwa tugas seorang guru adalah tugas yang mulia, guru merupakan sebuah profesi yang terhormat, untuk itu para guru agama Katolik masa kini harus menghormati profesi tersebut dan hidup di dalamnya dengan keteguhan panggilannya guna membawa perubahan bagi peserta didiknya. Menurut penulis, tugas guru agama Katolik pada masa kini memang sungguh berat, dalam memahami tugas tersebut penulis mencoba menjelaskan dulu arti "tugas" itu menurut Kamus Besar Bahasa Indonesia, "tugas” berarti, sesuatu yang wajib dikerjakan atau yang ditentukan untuk dilakukan; pekerjaan yang menjadi tanggung jawab seseorang.

Dari definisi tersebut ada hal yang perlu diperhatikan yaitu motivasi dalam mengajar, metode mengajar, dan tujuan pembelajaran yang jelas. Jelas dalam hal ini teladan utama guru agama Katolik adalah Yesus Kristus sendiri. Guru agama Katolik harus menjadi teladan iman yang mumpuni bagi siswa-siswinya, karena melalui kehidupan guru agama Katolik yang berintegritas serta memiliki kehidupan rohani yang berkualitas membuat para siswa tak sungkan menjadikan mereka contoh teladan yang patut diteladani. Dalam hal ini Guru agama Katolik harus menanamkan pengaruh melalui keteladanan hidupnya baik dalam perkataan dan perbuatan mengajar.

\subsection{Keteladanan Yesus sebagai Guru dan Relevansinya bagi Guru Agama Katolik}

Seorang guru agama Katolik harus memiliki karakter yang kuat seperti Yesus. Karakter berarti menyangkut kepribadian yang utuh dari seseorang, sehingga kepribadian sangat menentukan nilai kehidupan seseorang. Karakter atau kepribadian seorang Guru agama Katolik juga menentukan keberhasilan Guru dalam mendidik dan mengajar siswa sebagai pembimbing rohani dalam menumbuh-kembangkan iman murid-muridnya, karena guru agama Katolik tidak hanya sekedar sebagai pengajar ilmu saja, tetapi lebih daripada itu guru menjadi contoh dari kehidupan yang diajarkan dan yang terlihat dalam kehidupan seharihari.

Selain itu dalam menghadapi berbagai tantangan zaman dan tuntutan dunia pendidikan yang semakin berkembang guru agama Katolik perlu mengembangkan keterampilan mengajar. Yesus adalah contoh Guru yang benar-benar menciptakan keteladanan dalam mengajar. Maka, guru agama Katolik harus terampil dalam menciptakan suasana kelas yang kondusif sehingga proses belajar berjalan baik adalah sangat dibutuhkan. Guru agama Katolik harus terampil dalam menyampaikan materi ajar saja tetapi juga harus terampil untuk mengatasi segala 
hambatan belajar di kelas khususnya karena faktor murid yang tampak kurang antusias dan kurang berminat dalam mengikuti pelajaran di kelas.

Guru Pendidikan agama Katolik harus menguasai keterampilan dasar dalam menjalankan tugasnya. Penguasaan keterampilan dasar mulai dari pengenal karakter murid-muridnya, berani menjadi sahabat bagi para murid, terampil dalam mengajar, dan tidak kalah pentingnya seorang guru agama Katolik harus terlibat aktif dalam kehidupan bermasyarakat.

\section{KESIMPULAN}

Keunikan dan keagungan pengajaran Yesus dalam Injil seharusnya membuat kita sungguh merasa bangga bahwa kita memiliki teladan Guru yang sangat Agung. Yesus sebagai Guru dalam Injil telah menggunakan banyak metode yang berbeda dalam mendekati bermacam-macam pendengar historisnya sesuai dengan situasi dan keadaan mereka masing- masing, seperti perumpamaan, Amsal, pepatah, alegori, kiasan, perbandingan sederhana, bahasa simbolis, metafor, dialog, pertanyaan-pertanyaan (tanya jawab), permainan kata-kata, parallelisme, peringatan dan teguran, tanya jawab, paradoks, ironi, makna ganda sehingga menumbuhkan semangat belajar kepada para murid-Nya.

Selain Yesus menggunakan metode dalam pengajaran-Nya, Yesus sebagai Guru mempunyai keunikan-keunikan model pengajaran yang berbeda dengan para rabi Yahudi pada masanya. Tujuan semua metode dan model yang unik tersebut adalah untuk membawa para pendengar-Nya datang beroleh keselamatan, mengalami pertobatan, mengalami perubahan cara hidup, dan mengajarkan kasih.

Relevansi yang dapat dipelajari dari teladan Yesus sebagai guru agama Katolik dan pelaku pendidikan harus menyadari bahwa dalam mendekati para pendengar yang berbeda-beda, harus menggunakan pendekatan yang berbedabeda sesuai dengan situasi dan kebutuhan yang terdalam dari para pendengar. Sebagai murid-Nya dan sebagai pendidik di masa kini, harus berani meneladani Yesus sebagai Guru baik dalam membawa orang-orang datang untuk percaya kepada Yesus maupun dalam pendidikan, pengajaran, pelatihan, pembinaan iman anak-anak, murid-murid, di sekolah-sekolah umum maupun sekolah-sekolah Katolik.

\section{DAFTAR PUSTAKA}

Baskoro, Haryadi. 2018. Yesus Guru Profesional: Teladan Sang Kristus untuk Pendidikan Kristen Masa Kini. Yogyakarat: Lumela

Budiyanto, Agus Krisno. 2016. Sintaks 45 Model Pembelajaran dalam Student Centered Learning. Malang: Universsitas Muhhamadiyah Malang.

Jonch, Christian. 2007 “Yesus Sebagai Guru: Studi Inil Yohanes” dalam 
jurnal VERITAS edisi Juli 2007.

Leks, Steafan. (1987). Percakapan Tentang Mengikuti Yesus (Berdasarkan Alkitab). Yogyakarta: Kanisius.

Lembaga Alkitab Indonesia. 2016. Alkitab Deuterokanonika. Jakarta: Lembaga Alkitab Indonesia.

Price, J.M. (1968). Yesus Guru Agung. Bandung: Lembaga Literatur Baptis. Sibulian, Togardo. 2017. "Prespektif Kristologi Mengenai Yesus Guru Agung” dalam Jurnal STULOS edisi Juli 2018.

Tafonao,Talizaro. 2018. Penerapan Strategi Pengajaran Tuhan Yesus Terhadap Pencapaian TUjuan Pendidikan Agama Kristen. dalam prociding seminar Nasional 18-Januari, 24 Maret dan 6 April, Yogyakarta.

Yulianingsih, Dwiyati, dkk. 2019. Keterampilan Guru PAK Untuk Meningkatkan Minat Belajar Murid Dalam Proses Pembelajaran Di Kelas.dalam Jurna Fidei Vol.2 No.1 (June 2019). Available Online at http://www.stttawangmangu.ac.id/e-journal/index.php/fidei. 